\title{
Preceptor rewards: How to say thank you for mentoring the next generation of nurse practitioners
}

\author{
Suzanne H. Campbell \\ Fairfield University, suzanne.campbell@nursing.ubc.ca \\ JoEllen Hawkins \\ Boston College
}

Follow this and additional works at: https://digitalcommons.fairfield.edu/nursing-facultypubs

This is a pre-print of an article accepted for publication in Journal of the American Academy of Nurse Practitioners $(19,2007)$. The definitive version is available at www3.interscience.wiley.com.

\section{Repository Citation}

Campbell, Suzanne H. and Hawkins, JoEllen, "Preceptor rewards: How to say thank you for mentoring the next generation of nurse practitioners" (2007). Nursing and Health Studies Faculty Publications. 3.

https://digitalcommons.fairfield.edu/nursing-facultypubs/3

\section{Published Citation}

Campbell, S.H. \& Hawkins, J. (2007). Preceptor rewards: How to say thank you for mentoring the next generation of nurse practitioners, Journal of the American Academy of Nurse Practitioners, 19, 24-29.

This item has been accepted for inclusion in DigitalCommons@Fairfield by an authorized administrator of DigitalCommons@Fairfield. It is brought to you by DigitalCommons@Fairfield with permission from the rightsholder(s) and is protected by copyright and/or related rights. You are free to use this item in any way that is permitted by the copyright and related rights legislation that applies to your use. For other uses, you need to obtain permission from the rights-holder(s) directly, unless additional rights are indicated by a Creative Commons license in the record and/or on the work itself. For more information, please contact digitalcommons@fairfield.edu. 


\title{
RESEARCH \\ Preceptor rewards: How to say thank you for mentoring the next generation of nurse practitioners
}

\author{
Suzanne Hetzel Campbell, RNC, PhD, IBCLC (Assistant Professor) 1 \& Joellen W. Hawkins, \\ RNC, PhD, FAAN (Professor)2 \\ 1 Fairfield University School of Nursing, Fairfield University, Fairfield, Connecticut \\ 2 William F. Connell School of Nursing, Boston College, Chestnut Hill, Massachusetts \\ Correspondence \\ Suzanne Hetzel Campbell, Fairfield University \\ School of Nursing, Fairfield University, 1073 \\ North Benson Road, Fairfield, CT 06824. \\ Tel: 203-254-4000 x2578; Fax: 203-254-4126; \\ E-mail: scampbell@mail.fairfield.edu \\ Received: October 2005; accepted: May 2006
}

doi:10.1111/j.1745-7599.2006.00186.x

\section{Abstract}

Purpose: To answer the question how do faculty nurture and reward clinical preceptors and what supports do preceptors require?

Data Sources: Data came from the literature and from surveying a purposive sample of 26 faculty members teaching clinical courses and arranging precepted experiences for NP students at 26 public and private institutions across the United States. The vehicles for the survey were personal contact and email.

Conclusions: Schools offer preceptor rewards varying widely in their monetary value, from tuition and continuing education vouchers, verification of hours toward recertification, access to services and events on campus, reduced price or free admission to museums, cultural and sports events, and lectures. Faculty nurture preceptors by nominating them for awards, providing letters of reference, editing manuscripts, and collaborating on research projects. Supports for preceptors from the literature reflected NONPF guidelines (2000), and the policies of schools and clinical agencies, such as providing copies of program objectives and student credentials.

Implications for Practice and Education: As NP programs have proliferated, there is increased pressure on faculty to find, nurture, reward, and retain good preceptors. Faculty must continue to 
work with program and agency administrators to comply with policies and create preceptor rewards to recognize their gifts to us, to our schools, and to the profession.

Key words: clinical preceptors, nurse practitioner education, preceptor benefits 
Nurturing and Rewarding Clinical Preceptors

\section{Background}

Faculty responsible for clinical courses for nurse practitioner (NP) students have been struggling with the issue of nurturing and rewarding preceptors since the inception of one-on-one mentoring. As certification criteria became more stringent, clinical time increased to a minimum of 500-600 hours, depending upon specialty (American Academy of Nurse Practitioners, 2005; American Nurses Credentialing Center, 2005; National Certification Corporation for the Obstetric, Gynecologic and Neonatal Nursing Specialties, 2005; Pediatric Nursing Certification Board, 2005). These criteria have created more competition for clinical sites and greater burdens on clinical preceptors, who must adapt their practice flow to accommodate students (Hayes, 1994). An increase in the number of programs preparing NPs over the past decade, now numbering 335 (Berlin, Wilsey, \& Bednash, 2005), has meant more competition for clinical sites and preceptors. Clinicians are struggling with demands to see greater numbers of patients per clinical session and increased scrutiny of their clinical decision-making such as ordering diagnostic testing (Philip \& Berkman, 2001). New Medicare regulations require that the provider, under whose number billing occurs, be responsible for verifying and documenting all patient data. A preceptor can no longer simply refer to students' documentation (Schaffer, 2002). Clinicianshave more demands on their time, creating disincentives to being preceptors.

Costs of higher education are rising, particularly for programs in practice disciplines. Thus, it is difficult if not impossible to imagine paying clinical preceptors. The mean full-time salary for experienced NPs is $\$ 74,812$ (Tumolo \& Rollet, 2006), the median in Boston is $\$ 83,741$ (Salary Wizard, 2006), and the range from a national sample is $\$ 52,000$ to $\$ 140,000$ (Pulcini, Vampola, \& Levine, 2005). Extrapolating an hourly rate from these figures, it is clear 
that the cost per student would be prohibitive. Joint appointments might be possible in colleges and universities affiliated with medical centers, but certainly not in private colleges and universities without such affiliations. Some enlightened practices and agencies do reward clinicians for precepting, but others create penalties in the form of workload and salary adjustments. Acknowledging that precepting satisfies a professional obligation (Hayes, 1994), how do faculty address the challenge to find and retain preceptors against the competition with other programs? How can faculty nurture, support, and reward the clinicians who precept NP students?

\section{The Literature}

As of 2005, over 116,000 nurse practitioners were practicing in the United States (Phillips, 2006). Each of these persons had engaged in precepted experiences numbering hundreds of hours during her/his graduate education. What motivated preceptors to create clinical opportunities for these persons and for all students currently enrolled in NP programs?

Faculty in NP programs are competing for preceptors not only with each other, but also with faculty in physician assistant programs and medical schools (Sloand, Feroli, Bearss, \& Beecher, 1995). Competition with these programs that are often receiving federal dollars for education through Medicare (Bruccoleri, 2005) causes pressure on nursing programs, rarely recipients of this largesse.

Numerous authors have discussed the rewards offered by NP programs (Amelia, Brown, Resnick, \& McArthur, 2001; Haussler, 2001; Hayes, 1994; Hildebrandt, 2001; Lyon \& Peach, 2001). These rewards include: vouchers for tuition and continuing education courses, campus privileges, letters or certificates of appreciation, invitations to school events, and opportunities to participate in research and publications or presentations. Details of these preceptor rewards 
found in the literature appear in Table 1. In the National Organization of Nurse Practitioner Faculties (NONPF) publication, Partners in NP Education: A Preceptor Manual for NP Programs, Faculty, Preceptors, and Students (2000), Module III is entitled Preceptor Guidelines. In this document is a list of suggested rewards for preceptors. In addition to rewarding preceptors with gifts and other means of saying thank you, faculty also nurture preceptors through providing them with the support and resources they need to mentor students.

A considerable body of literature exists in which the authors have cited examples of supports and resources critical to the faculty-student-preceptor triad (Amelia et al., 2001; Gibson \& Hauri, 2000; Hildebrandt, 2001; Lyon \& Peach, 2001; NONPF, 2000; Sobralske \& Naegele, 2001). These are detailed in Table 2 . While we as faculty might not view these as rewards, preceptors view preparation for the role and for the individual student as essentials for taking on the challenge of precepting (Amelia et al.; Gibson \& Hauri; Lyon \& Peach; Sobralske \& Naegele).

In addition, faculty should not underestimate the importance of a nurturing and supportive faculty-preceptor relationship. Preceptors appreciate formal evaluation of how they are doing and site visits by faculty to provide a realistic view of students' performance and a forum for mutual feedback (Gibson \& Hauri, 2000). Clinical site visits provide faculty and preceptors an opportunity for face-to-face acknowledgment of the contribution of the preceptor and nurturing of the preceptor in that role.

What then might faculty consider in balancing the needs of students, limits of school resource and faculty time, and criteria for education of NPs in nurturing and rewarding clinical preceptors? What does the literature reveal and what new strategies might faculty consider to 
supplement the one-on-one precepting demanded by accreditation and certification requirements?

The Survey

To answer the question of what faculty are doing to nurture and reward preceptors, we conducted a survey of NP clinical faculty members from public and private colleges and universities across the United States.

Sample and methods. For this survey of faculty teaching nurse practitioner clinical courses and arranging precepted experiences for students, we used the attendance list of faculty at the 2005 NONPF conference, as well as surveying NP faculty colleagues to create a purposive sample of NP faculty across the country. The vehicles for the survey were personal contact and email. We posed the question, "What rewards do you offer clinical preceptors and what, if anything, do you do for preceptors as a school and personally?" The institutional review board at Boston College ruled this survey as exempt. At the 2005 NONPF conference, we approached faculty members to discuss the issue and asked for their business cards so we could email them the results, which we promised to do for all participants. We also sampled from the NONPF attendance list and emailed additional faculty to assure that the sample represented the full range of programs by geography, NP offerings and college or university demographics. Responses were received from all but two of the 28 faculty members queried.

The survey sample was comprised of 26 faculty members representing 26 different institutions across the United States. States included: Arizona, California, Colorado, Connecticut, Florida, Georgia, Illinois, Maine, Massachusetts, Michigan, Mississippi, New Hampshire, New York, Oregon, Pennsylvania, South Carolina, Virginia and Wisconsin. Eighteen schools are public and six private. Nineteen can be classified as large and seven as small. Twelve schools 
have medical centers and of those, nine are public and three private institutions. Twenty schools have other health professions programs such as medicine and physical therapy. Thus the sample represents the range of characteristics of institutions offering NP programs.

\section{Findings}

The number of reward options offered to preceptors ranged from zero to ten. Only one school offers no rewards to preceptors. Six schools offer one reward option, three schools offer two, five schools offer three, seven schools offer four, two schools offer five and two schools offer seven and ten options respectively. Rewards vary widely in their monetary value, from tuition and continuing education vouchers, verification of hours toward recertification, and a discount on registration for conferences sponsored by the school (see Table 3). Many schools offer access to services and programs on campus such as library privileges, borrowing software or other media, museum admission, reduced price or free admission to cultural events and lectures, and sports events. Interestingly, one school offers football tickets, but only to physicians. This is a preferred benefit for this cohort of preceptors.

School initiated preceptor awards include certificates and letters of appreciation, invitations to dinners and luncheons honoring preceptors and awards recognizing outstanding preceptors. Rewards that enhance the preceptors' credentials include invitations to serve on school advisory boards, a title such as adjunct clinical instructor, being listed in the college or university catalogue as clinical faculty, participation in research and/or publications, and manuscript editing services. Faculty members who are skilled authors and editors offer this service to clinical preceptors to encourage them to publish. They also write letters of reference and nominate preceptors for awards. Some schools give preceptors gifts such as school logo mugs, pens, notebooks, baseball caps, coolers, business card holders, or tote bags. Faculty 
provide in-service programs or presentations at clinical agencies for staff. Preceptors are invited as guest lecturers in the classroom or to be part-time paid clinical faculty.

Faculty spend money out of pocket for preceptor gifts, as do students. In a survey of faculty expenses out of pocket for preceptor gifts, the range was $\$ 70-\$ 800$ for one academic year with a mean of $\$ 260$ (Hawkins, 2005). Faculty and students often write personal thank you notes in addition to the formal letters or certificates sent by the school.

Survey participants added comments in their emails or in our face-to-face discussions of nurturing and rewarding preceptors. One wrote, "What is wrong with us!?!? We give almost nothing to our preceptors without whom we couldn't grow NPs". Another wrote: "Very little is done for the preceptors by anyone". ". . . here is a topic that has always burned at my soul", wrote one very experienced NP faculty member. We suspect this sentiment resonates with many, if not most NP faculty members.

\section{Implications for Practice and Education}

NP program faculty struggle with the procurement, cost, time and maintenance of precepted clinical experiences for students. The lack of standardized clinical experiences, especially for novice nurses in NP programs, has become a concern. There may be additional options for developing critical thinking skills and assisting novices to learn the terminology, have time to practice sequencing the physical examination, look up necessary information, and focus on the clinical picture without distractions or the fear of harming a live patient. These options include: web-enhanced instruction; computer-assisted simulation (CAS); and patient simulation mannequins. Supplementing face-to-face one-on-one preceptorships with technology can facilitate learning, lessen the burden on clinicians to serve as preceptors, and mitigate the 
enormous costs in faculty and clinician time for providing and managing the hundreds of hours of clinical preceptorships.

Research on the effectiveness of these options for student learning and clinical decision making is not extensive. Goolsby (2001) examined the effect of CAS on nurse practitioner student learning, knowledge gained, and transferability to clinical situations. The students in Goolsby's sample demonstrated that CAS led to more active learning, and reinforced signs and symptoms of various diagnoses. The repetition could serve them well in clinical settings. Goolsby did find that students misinterpreted some of the data, and that their reasoning processes were affected by the lack of a live patient contact.

Several authors reporting on web-based learning have offered preliminary data on the potential benefits of this technology, including changes in nursing practice, patient teaching, cultural assessment and communication practices (Atack, 2003; Clark \& Thornam, 2002), as well as the incorporation of specific content in community health, pharmacology, epidemiology and pathophysiology (Anderson \& Mercer, 2004; Bata-Jones \& Avery, 2004; Rose, Frisby, Hamlin, \& Jones, 2000; Wills \& Stommel, 2002; Yucha \& Princen, 2000) into a web-based format. Documenting the effect of web-based learning on clinical practice of NP students has yet to be done.

Finally, the use of patient simulated mannequins for training NP students prior to immersion in clinical experiences is new, with minimal research to support its benefits and challenges. Web-based enhancement of courses, CAS, and the use of realistic scenarios with simulated mannequins that breathe, have pulses, and can go into cardiac and respiratory distress, can be used to enhance active student learning in the classroom and provide opportunities to practice clinical decision-making prior to engagement with real patients. Preceptors are more 
likely to accept students who are well prepared for clinical experiences and be more satisfied mentoring such students. Moreover, in the future, some of the required clinical hours could be fulfilled with experiences provided through these technological innovations, lowering the human and monetary costs of creating, maintaining, and rewarding preceptors in clinical placements. Summary

Nurturing, supporting, and rewarding clinical preceptors is an ongoing concern for faculty in NP programs. When considering the needs of students, resources available, and criteria for education of NPs in selecting, nurturing, and rewarding clinical preceptors, faculty must remember that not all rewards are monetary. Being open to new options may help faculty to create new venues for clinical education and relieve the pressure on clinicians for one-on-one precepting as the only model for clinical experiences.

Faculty must continue to work with school administrators to nurture, support, and reward preceptors to assure that they are recognized for their gifts to us, to our schools, and to the profession. In the words of (Hildebrandt, 2001): "They [preceptors] are the unsung heroines and heroes of advanced practice nursing education" (p.179). 


\section{References}

Amelia, E.J., Brown, L., Resnick, B., \& McArthur, D.B. (2001). Partners for NP education: The 1999 AANP preceptor and faculty survey. Journal of the American Academy of Nurse Practitioners, 13, 517-523.

American Nurses Credentialing Center. (2005). Eligibility requirements. Retrieved October 14, 2005 from http://www.nursingworld.org/ancc/certification/certs/advprac/np.html

American Academy of Nurse Practitioners. (2005). Certification application. Retrieved October 14, 2005 from http://www.aanp.org/Certification/Certification+Application.htm

Anderson, E., \& Mercer, Z. (2004). Impact of community health content on nurse practitioner Practice: A comparison of classroom and web-based teaching. Nursing Education Perspectives, 25, 171-175.

Atack, L. (2003). Becoming a web-based learner: Registered nurses' experiences. Journal of Advanced Nursing, 44, 289-297.

Bata-Jones, B., \& Avery, M. D. (2004). Teaching pharmacology to graduate nursing students: Evaluation and comparison of web-based and face-to-face methods. Journal of Nursing Education, 43, 185-189.

Berlin, L.E., Wilsey, S.J., \& Bednash, G.D. (2005). 2004-2005 enrollment and graduations in baccalaureate and graduate programs in nursing. Washington, DC: AACN and NONPF.

Bruccoleri, R.E. (2005). Graduate medical education funding. Reston, VA: The American Medical Student Association.

Clark, L., \& Thornam, C. (2002). Using educational technology to teach cultural assessment. Journal of Nursing Education, 4, 117-120. 
Gibson, S.E. \& Hauri, C. (2000). The pleasure of your company: Attitudes and opinions of preceptors toward nurse practitioner preceptees. Journal of the American Academy of Nurse Practitioners, 12, 360-363.

Goolsby, M. (2001). The role of computer-assisted simulation in nurse practitioner education. Journal of the American Academy of Nurse Practitioners, 13, 90.

Hayes, E. (1994). Helping preceptors mentor the next generation of nurse practitioners Nurse Practitioner, 19 (6), 62-66.

Haussler, S. (2001). Nurses' use of tuition waivers: One university's experiences. Journal of Professional Nursing, 17, 147-150.

Hawkins, J.W. (2005). Faculty out-of-pocket expense survey. Unpublished manuscript. Boston College.

Hildebrandt, E. (2001). Preceptors: A perspective of what works. Clinical Excellence for Nurse Practitioners, 5, 175-180.

Lyon, D.E. \& Peach, J. (2001). Primary care providers' views of precepting nurse practitioner students. Journal of the American Academy of Nurse Practitioners, 13, 237-240.

National Certification Corporation for the Obstetric, Gynecologic and Neonatal Nursing Specialties. (2005). Nurse practitioner examinations. Retrieved October 14, 2005 from http://www.nccnet.org/public/pages/index.cfm?pageid=110

National Organization of Nurse Practitioner Faculties. (2000). Partners in NP education: A preceptor manual for NP programs, faculty, preceptors, \& students . Washington, DC: NONPF.

Pediatric Nursing Certification Board. (2005) Examination information. Retrieved October 14, 2005 from http://www.pncb.org/ptistore/control/exams/index 
Philip, E.P. \& Berkman, B. (2001). Biotechnology and managed care: Effects on health care cost, clinical practice, and education of health care professionals. In N.W. Veeder \& W. Peebles-Wilkins, Managed care services: Policy, programs, and research (pp. 31-49). New York: Oxford University Press.

Phillips, S.J. (2006). $18^{\text {th }}$ annual legislative update. The Nurse Practitioner, 31 (1), 6-38.

Pulcini, J., Vampola, D., \& Levine, J. (2005). Nurse practitioner practice characteristics, salary, and benefits survey, 2003. Clinical Excellence for Nurse Practitioners, 9 (4), 49-58.

Rose, M., Frisby, A., Hamlin, M., \& Jones, S. (2000). Evaluation of the effectiveness of a Webbased graduate epidemiology course. Computers in Nursing, 18, 162-167.

Salary Wizard. (2006). Salary Wizard calculator. Retrieved April 29, 2006, from http://swz.salary.com/salarywizard/layoutscripts/swzl_compresult.asp?narrowdesc=\&job $\underline{\text { altername }=\text { Nurse }+ \text { Practitioner } \& \text { state }}$

Schaffer, S.D. (2002). How NP preceptors can comply with Medicare requirements. The Nurse Practitioner, 27 (3), 10.

Sloand, E.D., Feroli, K., Bearss, N., \& Beecher, J. (1995). Confronting the cost of ambulatory-care training. Academic Medicine, 70, 949-950.

Sobralske, M. \& Naegele, L.M. (2001). Worth their weight in gold: The role of clinical coordinator in a family nurse practitioner program. Journal of the American Academy of Nurse Practitioners, 13, 537-544.

Tumolo, J. \& Rollet, J. (2006). 2005 salary survey results: A place at the table. Retrieved April 29, 2006, from http://nursepractitioners.advanceweb.com/common/editorial/editorial.aspx $? \mathrm{CC}=65135$ 
Wills, C., \& Stommel, M. (2002). Graduate nursing students' precourse and postcourse perceptions and preferences concerning completely web-based courses. Journal of Nursing Education, 41, 193-201.

Yucha, C., \& Princen, T. (2000). Insights learned from teaching pathophysiology on the World Wide Web. Journal of Nursing Education, 39, 68-72. 
Table 1

Preceptor Rewards From the Literature*

Free continuing education units for licensure and certification renewal

Waiving registration fees for conferences sponsored by school of nursing

Certificates of appreciation; plaque with gold plate for each year of precepting

Hand written personal thank you notes

Inviting preceptors to campus events

Nominating preceptors for awards-local, regional, and national

Publishing names and credentials of preceptors in college and university catalogues and other materials about the programs

Publishing news about preceptors in newsletters of the school and professional organizations

Inviting preceptors to receptions for graduate students and general school receptions

Gift of college bookstore vouchers or discounts

Access to library resources on campus or via the web

Invitations to sit on school advisory boards, focus groups

Honoring preceptors at a breakfast, luncheon, dinner, reception attended by school administrators, faculty and students

Creating preceptor training workshops

Tuition vouchers for individual preceptors or awarded to agencies

Adjunct or clinical faculty status

Parking privileges on campus

Letters of acknowledgment listing number of hours for recertification

Establishing a student-generated preceptor of the year award 
Table 1 (continued)

Recognizing preceptors at graduation

Inviting preceptors to participate in classes or attend classes on any topic on the course or program syllabuses

Identifying and developing continuing education programs requested by preceptors

Responding to individual needs of preceptors such as editorial help with manuscripts, goal statements for doctoral programs, support letters for grants

Providing complementary textbooks

Seeking sponsorship from pharmaceutical companies for educational programs

* Compiled from Amelia, Brown, Resnick, \& McArthur, 2001; Haussler, 2001; Hayes, 1994;

Lyon \& Peach, 2001; NONPF, 2000; Sobralske \& Naegele, 2001 
Table 2

Resources and Supports Provided to Preceptors From the Literature

Curriculum vitae or resumes for the student(s) to be precepted

Course syllabuses

Program, course and clinical objectives

Copies of student's credentials

The process for evaluation of the student and of the preceptor and site and copies of the evaluation forms to be used

Memorandum or letter of understanding

Preceptor, student and faculty roles and responsibilities

Guidelines for the selection of preceptors (included in NONPF criteria)

Site visit protocol

Faculty member responsible for the placement and contact information

List of preceptor rewards, options

References on how to be a preceptor-articles or on-line access to a preceptor website

Review of students' evaluation of them as preceptors

Opportunity to share clinical insights with students

Informal input into curriculum of the NP program

Students' clinical placements-where each student will have clinical experiences over the course of the program

Current list of texts for the clinical courses

Mission of the school and NP program philosophy 
Table 2 continued

* Compiled from Amelia, Brown, Resnick, \& McArthur, 2001; Hayes, 1994; Lyon \& Peach, 2001; NONPF, 2000; Sobralske \& Naegele, 2001 
Table 3

Options for Rewards Available to Preceptors*

Reward Option

\# of Schools \#Private \#Public Size

Big Small

Status/rank

124

$\begin{array}{lll}8 & 8 & 4\end{array}$

Certificate of recognition

118

$3 \quad 8 \quad 3$

Dinner/luncheon

$8 \quad 2$

$\begin{array}{lll}6 & 7 & 1\end{array}$

Continuing education talk

$7 \quad 2$

Gift

64

$\begin{array}{lll}5 & 6 & 1\end{array}$

Library privileges

63

$\begin{array}{lll}2 & 5 & 1\end{array}$

Verification of hours toward recertification

63

$\begin{array}{lll}3 & 5 & 1\end{array}$

Letter of thanks from school

5

Tuition waiver based on hours precepted

53

Gift from student

53

Gift from faculty out of pocket

4

Continuing education vouchers

$\begin{array}{lllll}4 & 3 & 1 & 2 & 2\end{array}$

Outstanding preceptor award

$\begin{array}{lllll}3 & 0 & 3 & 3 & 0\end{array}$

Invitation to serve on advisory board

Thank you note/letter from faculty

Faculty appointment with privileges

Break on conference registration fee

$\begin{array}{lllll}2 & 1 & 1 & 1 & 1\end{array}$

$\begin{array}{lllll}2 & 1 & 1 & 1 & 1\end{array}$

$\begin{array}{lllll}2 & 0 & 2 & 2 & 0\end{array}$

$\begin{array}{lllll}2 & 2 & 0 & 2 & 0\end{array}$


Table 3 Continued

Participate in projects, research

$\begin{array}{lllll}2 & 1 & 1 & 2 & 0\end{array}$

Faculty provide in-service program to agency $\quad 2 \quad 1 \quad 1 \quad 1 \quad 1$

Nomination for awards

$1 \quad 1 \quad 0 \quad 1 \quad 0$

Edit manuscripts

$1 \quad 1 \quad 0 \quad 1 \quad 0$

Software borrowing privileges

$\begin{array}{lllll}1 & 0 & 1 & 1 & 0\end{array}$

Access to museum, sports events

$\begin{array}{lllll}1 & 1 & 0 & 1 & 0\end{array}$

Football tickets-MDs only

$\begin{array}{lllll}1 & 1 & 0 & 1 & 0\end{array}$

Letters of reference

$\begin{array}{lllll}1 & 1 & 0 & 1 & 0\end{array}$

*several faculty noted the options can vary from year to year as schools struggle to find appropriate ways to thank preceptors $\mathrm{N}=26$ 